\section{Comment on “Major Australian-Antarctic Plate Reorganization at Hawaiian-Emperor Bend Time"}

\author{
Anahita A. Tikku ${ }^{1,2 *}$ and Nicholas G. Direen ${ }^{3,4}$
}

Whittaker et al. (Reports, 5 October 2007, p. 83) presented reconstructions for Australia and Antarctica showing a change in relative plate motion $\sim 53$ million years ago, coincident with an inferred major global plate reorganization. This comment addresses problematic areas in their assumptions and the geological consequences of their reconstructions.
$\mathrm{W}$ hittaker et al. (1) reported evidence of major Australia-Antarctic plate reorganization between 50 and 53 million years ago (Ma). The change in relative plate motion in their reconstructions is based on two assumptions. The first assumption is that the $>95$-million-yearold Leeuwin (Perth) fracture zone (2) offshore western Australia $\left(\sim 115^{\circ} \mathrm{E}, 37^{\circ} \mathrm{S}\right)$, southeast of the Naturaliste Plateau, is conjugate to the newly identified Perth South fracture zone, offshore Wilkes Land, Antarctica $\left(\sim 110^{\circ} \mathrm{E}, 65^{\circ} \mathrm{S}\right)$. The second is that the northwest-southeast direction of separation implied by these fracture zones persisted between the magnetic Quiet Zone Boundary (QZB, $95 \mathrm{Ma}$ ) and chron $24 \mathrm{o}(53 \mathrm{Ma})$. These assumptions are open to some debate. Specifically, the identification of the seafloor spreading magnetic anomalies and the Perth South fracture zone are both uncertain, and the new poles give rise to other geological inconsistencies.

Integrated interpretation of geophysical data from both the Australian and Antarctic margins indicates that the onset of breakup was complex

${ }^{1}$ ExxonMobil Upstream Research Company, Post Office Box 2189, Houston, TX 77252-2189, USA. ${ }^{2}$ Rensselaer Polytechnic Institute, Department of Earth and Environmental Sciences, 110 8th Street, Troy, NY 12180, USA. ${ }^{3}$ University of Tasmania, School of Earth Sciences, Private Bag 79, Hobart, TAS 7001, Australia. ${ }^{4}$ FrOG Tech Pty. Ltd., Post Office Box 145, Blackmans Bay, TAS 7052, Australia.

*To whom correspondence should be addressed. E-mail: anahita.a.tikku@exxonmobil.com

and diachronous with the oldest seafloor spreading anomalies identified as chron $32 y(3,4)$ and chron 33o (3) in the central sector of the AustralianAntarctic Basin, between 127 and $133^{\circ} \mathrm{E}$ on the Australian margin and $\sim 125$ and $128^{\circ} \mathrm{E}$ on the Antarctic margin. The Whittaker et al. (1) identification of seafloor spreading magnetic anomalies for chrons 33o, 34y, and the QZB in this sector is at odds with these interpretations, and any finite reconstruction poles older than chron $32 \mathrm{y}$ are speculative.

Colwell et al. (4) interpreted that magnetic anomalies landward of the identifications for chron 20 o (to the west) to chron 240 (to the east) along the Sabrina Coast Sector of the Antarctic margin (110 to $\left.124^{\circ} \mathrm{E}\right)$ possibly lie on transitional continental-oceanic crust with major magmatic components. This interpretation was based on the same profiles as the magnetic anomalies interpreted by (1), data collected by the Australian Government in 2001 and 2002. These results suggest that the magnetic anomalies landward of chron 20 o in this region may not be seafloor spreading isochrons, but could be serpentinized ridges analogous to the passive margins of Iberia and Labrador (e.g., 5, 6), and therefore cannot be used as constraints in the derivation of finite reconstructions.

Comparing the reconstructions of Whittaker et al. (1) and Tikku and Cande (2), we find that the poles for chrons $20 \mathrm{o}, 21 \mathrm{y}$, and $24 \mathrm{o}$ are statistically indistinguishable at the $95 \%$ confidence level (Table 1); only the poles for chrons $27 y$ and

Table 1. Finite rotations of relative motion for Australia with respect to East Antarctica.

\begin{tabular}{|c|c|c|c|c|c|}
\hline Anomaly & Age (Ma) & Latitude $\left({ }^{\circ} \mathrm{N}\right)$ & Longitude $\left({ }^{\circ} \mathrm{E}\right)$ & Rotation angle $\left({ }^{\circ}\right)$ & Source \\
\hline \multirow[t]{2}{*}{200} & 43 & 15.07 & 31.78 & 24.55 & (2) \\
\hline & & 14.92 & 32.50 & 24.51 & (1) \\
\hline \multirow[t]{2}{*}{$21 y$} & 46 & 14.00 & 33.34 & 24.70 & (2) \\
\hline & & 13.60 & 33.60 & 24.64 & (1) \\
\hline \multirow[t]{2}{*}{240} & 53 & 10.39 & 35.59 & 25.15 & (2) \\
\hline & & 9.01 & 36.00 & 25.06 & (1) \\
\hline \multirow[t]{2}{*}{$27 y$} & 61 & 9.95 & 36.52 & 25.55 & $(2)$ \\
\hline & & 5.51 & 38.57 & 25.30 & (1) \\
\hline \multirow[t]{2}{*}{$32 y$} & 71 & 9.48 & 37.02 & 26.13 & (2) \\
\hline & & 1.04 & 40.65 & 25.85 & (1) \\
\hline
\end{tabular}

$32 \mathrm{y}$ differ, with those two poles being geographically very close to the 24 o pole for (2) and further to the southeast for (1). The geological consequences are very different for these two scenarios.

In the chron $32 y$ reconstruction of (2), the Leeuwin fracture zone is roughly aligned with the Vincennes fracture zone $\left(\sim 102^{\circ} \mathrm{E}, 63^{\circ} \mathrm{S}\right)$, which bounds the eastern margin of the Bruce Rise offshore Antarctica, whereas it is aligned with the Perth South fracture zone in the chron $32 \mathrm{y}$ reconstruction of $(1)$. Because the Perth South fracture zone is $\sim 400 \mathrm{~km}$ east of the Vincennes fracture zone, the Australian plate is shifted eastward by this amount in the reconstruction of (1) with respect to (2). The geological justifications (1) cited for this shift of Australia are threefold. First, Gaina et al. (7) recently identified Mesozoic seafloor spreading anomalies (M2 to M9) north of the Bruce Rise thought to be conjugate to crust formed west of the Naturaliste Plateau on the Indian plate. Second, the shift apparently aligns Archean-early Paleozoic terranes on the conjugate Australian and Antarctic plates (8). Third, the reconstructions of (2) for chrons $33 \mathrm{o}$ and $34 \mathrm{y}$ produced an overlap of $\sim 140 \mathrm{~km}$ between Tasmania and Antarctica. Although these constraints could be valid, they are not tight or definitive. Magnetic anomaly identifications north of the Bruce Rise are very noisy and therefore speculative. Based on seismic reflection data, Stagg et al. (9) characterized this
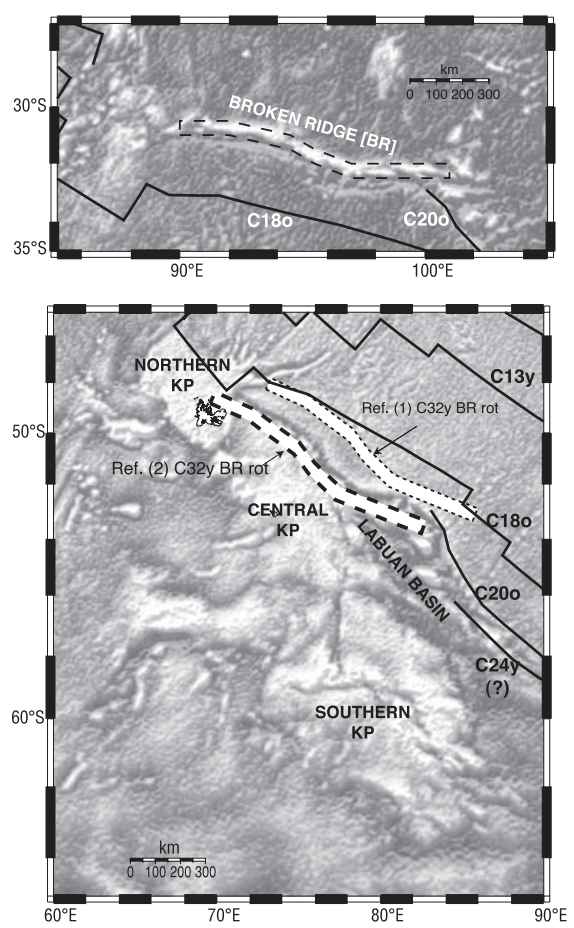

Fig. 1. Satellite-derived free-air gravity maps (14) of (top) Broken Ridge (BR) and (bottom) Kerguelen Plateau (KP), illuminated from $\mathrm{N} 0^{\circ} \mathrm{E}$ and $\mathrm{N} 270^{\circ} \mathrm{E}$ along with regional isochrons (15). On the top, BR (as outlined on the bottom) is reconstructed using the finite rotation parameters of (1) and (2) for chron 32y. 
crust as being highly variable in character and not definitely oceanic in origin. With $>350$ million years between the early Paleozoic and chron 32 y (71 Ma), apparent net eastward shift of Australian onshore basement terranes may be partly related to earlier events (e.g., documented Paleozoic orogenies or Pangea breakup). In addition, the Antarctic piercing points proposed in (1) are oversimplified with another deformed 1.69-billionyear-old basin (10) occurring west of Archean rocks shown in (1) and ice cover, making direct correlations speculative. Last, the amount of overlap in the reconstructions of (2) between Tasmania and Antarctic at chron $32 \mathrm{y}$, which is now taken to be the oldest isochron $(3,4)$, is extremely minor.

A geological constraint appears to be violated by moving Australia eastward (Fig. 1), suggesting that the chron $32 \mathrm{y}$ pole of (2) is more likely than that of (1). Broken Ridge and Kerguelen Plateau are conjugate rifted plateaus formed $\sim 88$ to $100 \mathrm{Ma}(11)$, but in the chron $32 \mathrm{y}$ reconstruction of (1) the eastern end of the ridge falls on oceanic crust dated between chrons $18 \mathrm{y}$ and 20 o (40 to $43 \mathrm{Ma}$ ). The entire ridge shifts $\sim 215$ to $260 \mathrm{~km}$ to the east using the poles of (1) versus those of (2). This implied amount of compression is greater than can be reconciled with contemporaneous deformation in the Kerguelen Plateau and Labuan Basin (12).
Finally, evidence supporting the existence of the proposed northwest-southeast trending Perth South fracture zone on the Antarctic plate, presuming it is a conjugate to the Perth fracture zone, is not demonstrably robust. Whittaker et al. (1) suggested that the fracture zone is expressed in the downward continued satellite-derived gravity field, but the expression in that field is weak. Moreover, downward continuation is not a conventional technique for identifying fracture zones, as it is prone to amplification of noise. Furthermore, there is no observed offset in magnetic anomalies across the suggested fracture zone that would support its presence.

In summary, we contend that the published evidence does not support the hypothesized major change in relative plate motion between Australia and Antarctica at the Hawaiian-Emperor bend time as argued by Whittaker et al. (1). The data do support the hypothesis that the rate of extension increased at chrons $24 \mathrm{y}(53 \mathrm{Ma}), 21 \mathrm{y}$ (43 Ma), and 18o (40 Ma) (13). More data are required to verify the style of development and age of the conjugate Cretaceous AustralianAntarctic passive margins.

\section{References}

1. J. M. Whittaker et al., Science 318, 83 (2007).

2. A. A. Tikku, S. C. Cande, Earth Planet. Sci. Lett. 180, 117 (2000).
3. J. Sayers, P. A. Symonds, N. G. Direen, G. Bernardel, in Non-Volcanic Rifting of Continental Margins: A Comparison of Evidence from Land and Sea, R. C. L. Wilson, R. B. Whitmarsh, B. Taylor, N. Frotzheim, Eds. (Geological Society, London, 2001), pp. 51-76.

4. J. B. Colwell, H. M. J. Stagg, N. G. Direen, G. Bernardel, I. Borissova, in Antarctica: Contributions to Global Earth Sciences, D. K. Fütterer, D. Damaske, G. Kleinschmidt, H. Miller, F. Tessensohn, Eds. (Springer-Verlag, Berlin, 2006), pp. 327-340.

5. J.-C. Sibuet, S. Srivastava, G. Manataschal, J. Geophys. Res. 112, B06105 (2007).

6. N. G. Direen, I. Borissova, H. M. J. Stagg, J. B. Colwell, P. A. Symonds, in Imaging, Mapping and Modelling Continental Lithosphere Extension and Breakup G. D. Karner, G. Manatschal, L. M. Pinheiro, Eds. (Geological Society, London, 2007), pp. 235-261.

7. C. Gaina, R. D. Müller, B. Brown, T. Ishihara, S. Ivanov, Geophys. J. Int. 170, 151 (2007).

8. C. A. Finn, D. Moore, D. Damaske, T. Mackey, Geology 27, 1087 (1999).

9. H. M. J. Stagg, J. B. Colwell, I. Borissova, T. Ishihara, G. Bernardel, Terra Antarctica 13, 13 (2006).

10. R.-P. Menot et al., Gond. Res. 8, 1 (2005).

11. T. A. Davies, B. P. Luyendyk, DSDP Initial Reports 26 (U.S. Government Printing Office, Washington, DC, 1974).

12. M. A. Munschy, Y. Rotstein, R. Schlich, M. F. Coffin, J. Geophys. Res. 98, 6367 (1993).

13. A. A. Tikku, S. C. Cande, J. Geophys. Res. 104, 661 (1999).

14. D. T. Sandwell, W. H. F. Smith, Geophys. J. Int. 163, 79 (2005).

15. R. D. Müller, W. R. Roest, ].-Y. Royer, L. M. Gahagan, J. G. Sclater, J. Geophys. Res. 102, 3211 (1997).

29 February 2008; accepted 25 June 2008 10.1126/science. 1157163 